\title{
Omega-3 polyunsaturated fatty acids of fish and their role in cancerous cell lines: A review of in-vitro studies
}

\author{
Farheen Jameel, Priyanka Agarwal, Mohd. Arshad, Mohd. Serajuddin
}

Received - 25 November 2018/Accepted - 02 February 2019. Published online: 31 March 2019; Inland Fisheries Institute in Olsztyn, Poland Citation: Jameel F., Agarwal P., Arshad M., Serajuddin M. 2019 - Omega-3 polyunsaturated fatty acids of fish and their role in cancerous cell lines: A review of in-vitro studies - Fish. Aquat. Life 27: 47-63.

\begin{abstract}
Fish are a major dietary source of $n-3$ and $n-6$ polyunsaturated fatty acids (PUFAs) in humans since the human body lacks the necessary enzymes required to synthesize them. Diets rich in fish oil containing n-3 fatty acids have been shown to lower the incidence rates of cancer. They have also been shown to have cytotoxic or anti-proliferative effects on a variety of human cancer cell lines, and they are known to nurture overall human health without any observable side effects. The present review focused on in-vitro research findings regarding the apoptotic and anti-proliferative role of $\mathrm{n}-3$ fatty acids FAs that highlight the important mechanisms and pathways of their action in inhibiting the progression of cancer. A survey of the literature indicated the paucity of information on the use of n-3 FAs in combination with other anticancer substances. Therefore, further research needs to be undertaken on the use of n-3 FAs in combination with other anticancer phytochemicals and drugs, the use of antibodies as specific carriers of n-3 FAs, and different increasing ratios of n-3/n- 6 FAs that not only control the side effects of chemotherapy but also enhance its efficacy and selectivity. These FAs might also prove to be a pioneer therapy against cancer.
\end{abstract}

Keywords: anti-proliferation, apoptosis, arachidonic acid, combination chemotherapy, n-3 fatty acids

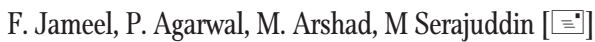

Department of Zoology, University of Lucknow

Lucknow-226007, U.P., India

e-mail: lu.fisheries@gmail.com

\section{Introduction}

Fish are highly recommended to be included in the human diet because of the content in the muscles of polyunsaturated fatty acids (PUFAs), essential amino acids, fat-soluble vitamins, and micro and macro elements (Mahmoud et al. 2007, Łuczyńska et al. 2008, Ljubojevic et al. 2013). Fish are the major dietary source for biologically active omega (n)-3 and omega (n)-6 PUFAs, which are beneficial to human health (Suzuki et al. 1995, Domingo 2007, Guil-Guerrero 2007, Huynh 2007, Ugoala et al. 2009, Sharma et al. 2010). These PUFAs are deposited in the phospholipids of cell membranes (Schmitz and Ecker 2008) and are known to perform several specific cell functions, inter alia, maintaining cell membrane structure, membrane fluidity, cell signaling, and cell to cell communication (Colomer et al. 2007). It has been reported that $\mathrm{n}-3$ fatty acids (FAs) can reduce the risk of neurological disorders (Crawford 1993), coronary artery disease, rheumatoid arthritis, and cancer (Simopoulos 2002). Epidemiological studies carried out in Japan and in the Mediterranean regions showed a low incidence rate of cancer in populations that consumed diets rich in fish oils containing n-3 FAs (Baracos and Mazurak 2004, Gerber 2012). A number of in-vitro studies suggest the cytotoxic or anti-proliferative effects of n-3 FAs 
on a variety of human cancer cell lines, including A549 (Yang et al. 2013), BxPC3 (Funahashi et al. 2008), MDA-MB-231 (Barascu et al. 2006), etc., without exerting any adverse effect on normal cells (Cantrill and Ells 1997, Griffiths et al. 1997, Solomon et al. 1998, Das 1999). Roynette et al. (2004) reported that n-3 FAs increased cancer cell apoptosis, decreased tumor cell growth, promoted cell differentiation, and limited angiogenesis. The present work aimed to review research findings based on the cytotoxic or anti-proliferative effects of n-3 fatty acids (FAs) that highlight the important mechanisms and pathways of their action that inhibit the progression of cancer. Efforts were also made to discuss the use of n-3 FAs in combination with other anticancer substances such as phytochemicals and drugs in order to control the side effects of drugs, and also to increase their efficacy.

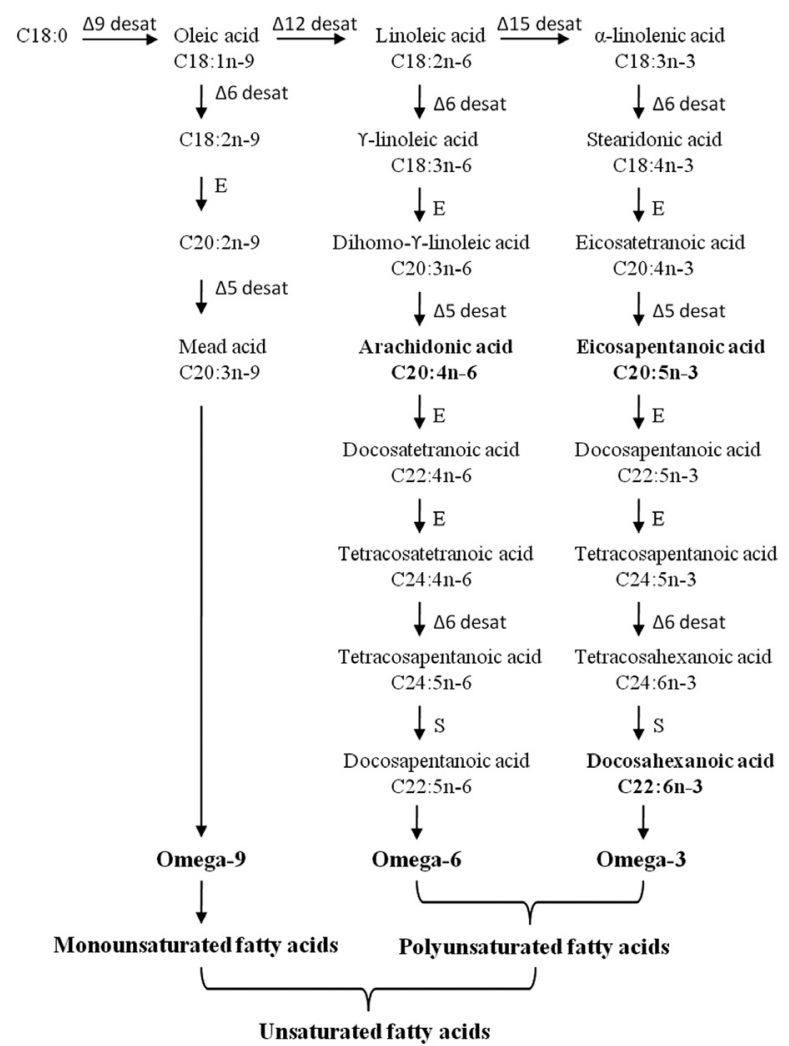

Figure 1. Biosynthetic pathways of n-3 and n-6 FAs from n-3, n-6, and n-9 C18 precursors.

Abbreviations : $\mathrm{C}=$ number of carbon atoms; $\mathrm{n}=$ position of first double bond; $\Delta 5$ desat, $\Delta 6$ desat, $\Delta 9$ desat, $\Delta 12$ desat, $\Delta 15$ desat $=$ Fatty acyl desaturases; $\mathrm{E}=$ Fatty acyl elongases; $\mathrm{S}=$ Chain shortening.

\section{Materials and methods}

The authors conducted a survey of research articles on n-3 and n-6 FAs of fish and effect of n-3 FAs on cancer cell lines. The search included publications spanning 36 years from 1981 to 2017, and the data were collected using the electronic databases PubMed, Google Scholar, Science Direct, Scopus, and Springer. The study did not incorporate abstracts of conferences, symposia, or patents because they contained inadequate information. The literature was scanned to examine how n-3 and n-6 FAs are synthesized in fish (Fig. 1), why these are essential for humans to ingest them with their diets, and how they affect human cancer cells in vitro. The mechanisms of action of n-3 FAs on cancer cells were evaluated and compiled into figures using Microsoft PowerPoint (Figs. 3, 4, 5). In vitro studies elucidating the anti-proliferative or apoptotic activity of n-3 FAs on different human cancer cell lines are summarized in Table 3.

\section{n-3 and n-6 FAs in fish}

Omega-3 and n-6 FAs are considered to be essential nutrients in the human diet because the human body is incapable of synthesizing them (Omar et al. 2010). However, these FAs are synthesized by aquatic micro-organisms that are consumed by fish, and, thus, they are distributed throughout the aquatic food web (Napier 2002). Therefore, fish are an important dietary source of these FAs for humans (Sushchik et al. 2007, Jabeen and Chaudhary 2011). No vertebrates, including human beings, can synthesize n-3 and n-6 FAs de novo because they lack $\Delta 12$ and $\Delta 15$ desaturase enzymes, without which alpha-linolenic acid (ALA, 18:3 n-3) and linoleic acid (LA, 18:2 n-6) cannot be formed from oleic acid (18:1 n-9); thus, ALA and LA are essential fatty acids in all vertebrate diets (Tocher 2003). The FA desaturases that introduce ethylenic bonds at carbon positions 12 and 15 from the carboxyl end of the molecule are termed $\Delta 12$ and $\Delta 15$ desaturases, respectively (Higashi and Murata 1993). Fish ingest short chain precursors (18:3 n-3, 
ALA and 18:2 n-6, LA) by consuming phytoplankton and zooplankton, which synthesize these FAs, and, thus, they are concentrated in the food chain (Almatsier 2003). These can be further desaturated and elongated to form C20 (20:5 n-3, 20:4 n-6) and C22 (22:6 n-3) FAs, which are considered to be physiologically essential (Tocher 2003). However, humans have a restricted capacity to synthesize these C20 and C22 FAs from short chain precursors. The biosynthetic pathway of n-3 and n-6 FAs from n-3 and n-6 C18 precursors is shown in Fig. 1. Fish are heterogeneous groups living in different habitats characterized by different environmental conditions. A number of researchers such as Ratkowsky et al. (1996), Kinsella (1988), Saito et al. (1999), Haliloglu et al. (2004), and Çelik et al. (2005) report that the composition of n-3 and n-6 FAs differ in different fish groups and species because of differences in their environmental conditions, diet, age, and maturity. Freshwater fish contain low levels of n-3 FAs compared to marine and estuarine fish because of differences in their feeding habits (Rahman et al. 1995). Therefore, the tissues of marine fish are preferable for use in diets to treat cancer. Freshwater fish feed primarily on phytoplankton and plant vegetation, whereas marine fish feed on small planktonic animals rich in PUFAs (Brett and Müller-Navarra 1997). The amounts of n-3 and n-6 FAs are elevated in fish inhabiting cold waters since these FAs enhance tolerance to low water temperatures (Stancheva et al. 2014). The two families of FAs (n-3 and n-6) are not inter-convertible and are functionally and metabolically distinct from each other (Simopoulos 2002). Therefore, $\mathrm{n}-3 / \mathrm{n}-6$ ratio can be a good index when comparing the relative nutritional values of different fish, and higher n-3/n-6 ratios are frequently cited as indicators of high nutritional value (Dhaneesh et al. 2012). The content of n-3 and n-6 FAs and their ratios in freshwater and marine fish are listed in Tables 1 and 2.

\section{Chemistry of n-3 and n-6 FAs}

Triacylglycerols in fish are invariably oils and FAs of lipids that are rich in long hydrocarbon chains with greater numbers of double bonds, and they play important roles in animal nutrition, including human beings. FAs with one or many double bonds are termed monounsaturated FAs (MUFAs) and polyunsaturated FAs (PUFAs), respectively (Johnson et al. 2009). The two families of PUFAs namely the n-3 and $n-6$ series, are derived from $\alpha$-linolenic acid (ALA, 18:3 n-3) and linoleic acid (LA,18:2 n-6), respectively. The FAs in the $n-3$ series are docosahexaenoic acid (DHA, 22:6 n-3) and eicosapentaenoic acid (EPA, 20:5 n-3), while the fatty acids in the n- 6 series are arachidonic acid (AA, 20:4 n-6) and docosapentaenoic acid (DPA, 22:5 n-6) (Sahena et al. 2009). Fish oils are rich in FAs with three or more double bonds that are considered to be important in the human diet. The details of the chemical structure of FAs are shown in Fig. 2.
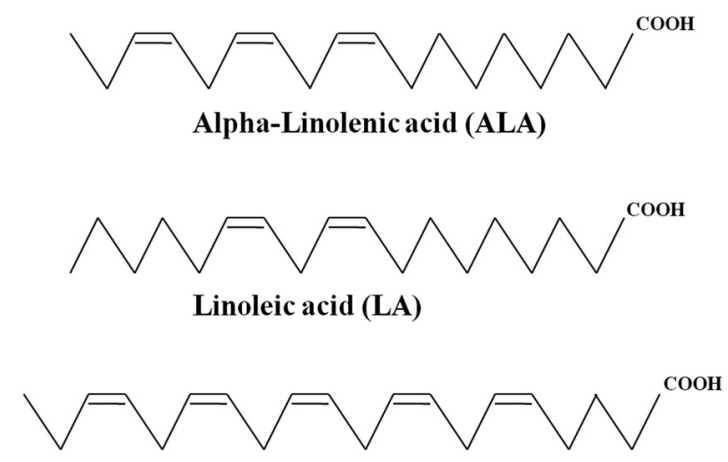

Eicosapentaenoic acid (EPA)

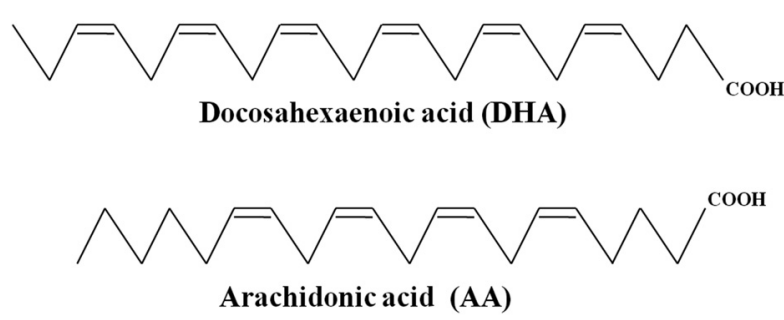

Figure 2. Structure of some biologically essential n-3 and n-6 FAs.

\section{n-3 FAs in cancer}

Cancer develops from genomic disturbances in cells triggered by genetic, organismic, or environmental factors that affect all the physiological conditions of cells including differentiation, division, migration, 
Farheen Jameel et al.

Table 1

PUFA profile of some important freshwater fish

\begin{tabular}{|c|c|c|c|c|c|c|c|}
\hline \multirow[b]{2}{*}{ Species } & \multirow[b]{2}{*}{ Source } & \multirow{2}{*}{$\begin{array}{l}\text { Total lipid } \\
\text { (g/ } 100 \mathrm{~g})\end{array}$} & \multirow{2}{*}{$\begin{array}{l}\text { Total } \\
\text { PUFA (\% } \\
\text { of Total } \\
\text { Lipid) }\end{array}$} & \multicolumn{2}{|c|}{ n-3 PUFA (\%) } & \multicolumn{2}{|l|}{ n-6 PUFA (\%) } \\
\hline & & & & EPA & DHA & $\mathrm{AA}$ & $n-3 / n-6$ \\
\hline Silurus glanis & Stancheva et al. 2014 & - & $21.64 \pm 1.51$ & $1.85 \pm 0.32$ & $6.17 \pm 0.35$ & $6.42 \pm 0.55$ & $0.93 \pm 0.07$ \\
\hline Pangasius pangasius & Asmah et al. 2014 & $7.96 \pm 1.06$ & 12.09 & $2.45 \pm 1.74$ & $0.23 \pm 0.12$ & - & - \\
\hline Aspius aspius & Ljubojevic et al. 2013 & $2.78 \pm 0.11$ & $24.60 \pm 0.3$ & $3.09 \pm 0.11$ & $5.22 \pm 0.1$ & $2.71 \pm 0.12$ & $1.29 \pm 0.03$ \\
\hline Abramis brama & Ljubojevic et al. 2013 & $3.24 \pm 0.15$ & $17.07 \pm 0.27$ & $3.94 \pm 0.11$ & $2.58 \pm 0.16$ & $2.18 \pm 0.00$ & $1.53 \pm 0.06$ \\
\hline Barbus barbus & Ljubojevic et al. 2013 & $7.78 \pm 0.15$ & $26.31 \pm 0.27$ & $5.41 \pm 0.1$ & $5.55 \pm 0.09$ & $1.48 \pm 0.06$ & $2.04 \pm 0.03$ \\
\hline Cyprinus carpio & Ljubojevic et al. 2013 & $7.13 \pm 0.1$ & $19.7 \pm 0.27$ & $1.36 \pm 0.08$ & $0.87 \pm 0.08$ & $2.42 \pm 0.09$ & $0.44 \pm 0.02$ \\
\hline Acipenser ruthenus & Ljubojevic et al. 2013 & $5.39 \pm 0.14$ & $22.17 \pm 0.37$ & $4.93 \pm 0.09$ & $3.79 \pm 0.09$ & $1.54 \pm 0.08$ & $2.9 \pm 0.19$ \\
\hline Esox lucius & Ljubojevic et al. 2013 & $1.61 \pm 0.06$ & $28.15 \pm 0.24$ & $1.94 \pm 0.08$ & $7.58 \pm 0.26$ & $3.85 \pm 0.14$ & $1.0 \pm 0.04$ \\
\hline Catla catla & Jakhar et al. 2012 & $1.2 \pm 0.08$ & 12.50 & 1.9 & 5.4 & - & 6.544 \\
\hline Labeo rohita & Jakhar et al. 2012 & $2.9 \pm 0.21$ & 15.84 & 1.29 & 3.74 & 2.87 & 1.046 \\
\hline Clarius batrachus & Jakhar et al. 2012 & $7.90 \pm 0.63$ & 25.56 & 2.10 & 3.76 & - & 0.706 \\
\hline Pangasiano hypophthalmus & Jakhar et al. 2012 & $4.98 \pm 0.38$ & 23.37 & 1.93 & 4.48 & 0.98 & 0.74 \\
\hline Channa micropellets & Omar et al. 2010 & $5.8 \pm 2.2$ & 36.40 & $5.1 \pm 1.1$ & $13.9 \pm 3.5$ & $11.4 \pm 2.3$ & 1.19 \\
\hline Schizothorax zarudnyi & Rahimabadi et al. 2009 & $6.36 \pm 0.16$ & 21.996 & $6.514 \pm 0.108$ & $9.425 \pm 0.389$ & $2.567 \pm 0.052$ & 3.90625 \\
\hline Schizocypris altidorsalis & Rahimabadi et al. 2009 & $4.52 \pm 0.14$ & 15.775 & $7.098 \pm 0.116$ & $4.391 \pm 0.740$ & $1.527 \pm 0.029$ & 4.90196 \\
\hline Alburnus mossulensis & Cengiz et al. 2009 & - & 31.76 & $1.54 \pm 0.36$ & $3.97 \pm 0.35$ & $4.79 \pm 0.65$ & 0.39 \\
\hline Chondrostoma regium & Cengiz et al. 2009 & - & 55.59 & $17.30 \pm 0.98$ & $16.82 \pm 1.01$ & $26.89 \pm 1.31$ & 3.53 \\
\hline Barbus rajonorum & Cengiz et al. 2009 & - & 69.48 & $13.39 \pm 1.12$ & $26.89 \pm 1.31$ & $10.12 \pm 0.75$ & 2.61 \\
\hline Carasobarbus luteus & Cengiz et al. 2009 & - & 56.39 & $6.87 \pm 0.78$ & $11.97 \pm 0.81$ & $12.27 \pm 0.95$ & 1.11 \\
\hline Leuciscus lepidus & Cengiz et al. 2009 & - & 59.78 & $6.25 \pm 0.69$ & $27.08 \pm 1.26$ & $9.14 \pm .085$ & 2.31 \\
\hline Acanthobrama marmid & Cengiz et al. 2009 & - & 48.87 & $7.97 \pm 1.01$ & $10.75 \pm 0.78$ & $10.67 \pm 0.68$ & 1.04 \\
\hline Cyprinion macrostomus & Cengiz et al. 2009 & - & 72.65 & $20.15 \pm 1.52$ & $22.19 \pm 1.00$ & $11.33 \pm 0.96$ & 2.99 \\
\hline Liza abu & Cengiz et al. 2009 & - & 9.75 & $0.65 \pm 0.07$ & $0.72 \pm 0.01$ & $0.75 \pm 0.01$ & 0.67 \\
\hline Silurus triostegus & Cengiz et al. 2009 & - & 57.19 & $10.87 \pm 0.86$ & $20.61 \pm 1.11$ & $9.86 \pm 0.36$ & 2.5 \\
\hline Piaractus brachyponus & Rahman et al. 1995 & $34.00 \pm 0.02$ & $34.00 \pm 0.20$ & 0.05 & 0.04 & 0.65 & - \\
\hline Monopterus albus & Rahman et al. 1995 & $6.25 \pm 0.38$ & $6.25 \pm 0.38$ & 2.66 & 0.21 & 0.67 & - \\
\hline Channa striatus & Rahman et al. 1995 & $3.25 \pm 0.63$ & $3.25 \pm 0.63$ & 0.32 & 1.54 & 2.22 & - \\
\hline Leptobarbus hoevenii & Rahman et al. 1995 & $7.92 \pm 0.16$ & $7.92 \pm 0.16$ & 0.15 & 0.71 & 1.30 & - \\
\hline Aristichthys nobilis & Rahman et al. 1995 & $1.75 \pm 0.87$ & $1.75 \pm 0.87$ & 0.26 & - & 14.0 & - \\
\hline $\begin{array}{l}\text { Hypophthalmichthys } \\
\text { molitrix }\end{array}$ & Rahman et al. 1996 & $7.08 \pm 0.48$ & $7.08 \pm .48$ & 0.04 & 0.79 & 0.84 & - \\
\hline Catla catla & Rahman et al. 1995 & $1.92 \pm 0.56$ & $1.92 \pm 0.56$ & 0.19 & 0.07 & 0.43 & - \\
\hline Clarias gariepinus & Rahman et al. 1995 & $20.00 \pm 0.20$ & $20.00 \pm 0.20$ & 0.08 & 0.14 & 1.30 & - \\
\hline Puntius gonionotus & Rahman et al. 1995 & $5.17 \pm 0.64$ & $5.17 \pm 0.64$ & 0.22 & - & 0.45 & - \\
\hline Anguilla mauritiana & Rahman et al. 1995 & $10.67 \pm 0.94$ & $10.67 \pm 0.94$ & 3.48 & 0.89 & 2.48 & - \\
\hline Pagasius pangasius & Rahman et al. 1995 & $5.67 \pm 0.39$ & $5.67 \pm 0.39$ & 0.08 & - & - & - \\
\hline Trichogaster trichopterus & Rahman et al. 1995 & $4.50 \pm 0.03$ & $4.50 \pm 0.03$ & 0.41 & 1.57 & 0.66 & - \\
\hline Trichogaster pectoralis & Rahman et al. 1995 & $1.17 \pm 0.05$ & $1.17 \pm 0.05$ & 0.44 & 1.88 & 0.24 & - \\
\hline Oreochromis mossambicus & Rahman et al. 1995 & $2.75 \pm 0.09$ & $2.75 \pm 0.09$ & 0.84 & - & 0.53 & - \\
\hline
\end{tabular}

and angiogenesis (Hanahan et al. 2000). Cancer cells develop resistance to cell death by down regulating the function of pro-apoptotic proteins and increasing the amount of anti-apoptotic molecules (Fulda et al.
2009). Research is being carried out globally to identify dietary components based on natural products that can be used as anticancer substances, in addition to chemically synthesized compounds. In vitro 
Table 2

PUFA profile of some important marine fish

\begin{tabular}{|c|c|c|c|c|c|c|c|}
\hline \multirow[b]{2}{*}{ Species } & \multirow[b]{2}{*}{ Source } & \multirow{2}{*}{$\begin{array}{r}\text { Total lipid } \\
(\mathrm{g} / 100 \mathrm{~g})\end{array}$} & \multirow{2}{*}{$\begin{array}{l}\text { Total } \\
\text { PUFA } \\
\text { (\% of Total } \\
\text { Lipid) }\end{array}$} & \multicolumn{2}{|l|}{ n-3 PUFA } & \multicolumn{2}{|l|}{ n-6 PUFA } \\
\hline & & & & $\mathrm{EPA}$ & DHA & $\mathrm{AA}$ & $n-3 / n-6$ \\
\hline Rainbow sardine & Homayooni et al. 2014 & - & $43.74 \pm 1.61$ & $15.39 \pm 0.73$ & $17.45 \pm 2.09$ & $2.10 \pm 0.29$ & $3.74 \pm 0.05$ \\
\hline Hilsa clupea macrura & Asmah et al. 2014 & $10.97 \pm 1.61$ & 27.82 & $11.83 \pm 0.02$ & $5.96 \pm 0.31$ & - & - \\
\hline Epinephelus tauvina & Dhaneesh et al. 2012 & 3.55 & 32.71 & 13.05 & 8.94 & 1.68 & 1.46 \\
\hline Carangoides orthogrammus & Dhaneesh et al. 2012 & 4.21 & 32.52 & 13.86 & 9.29 & 1.98 & 1.49 \\
\hline Tylosurus crocodilus crocodilus & Dhaneesh et al. 2012 & 4.56 & 35.11 & 15.06 & 9.34 & 1.11 & 1.61 \\
\hline Lutjanus gibbus & Dhaneesh et al. 2012 & 4.78 & 30.34 & 15.81 & 8.27 & 1.32 & 1.91 \\
\hline Seriola lalandi & Dhaneesh et al. 2012 & 3.11 & 31.22 & 15.70 & 9.82 & 1.57 & 1.6 \\
\hline Thunnus albacares & Dhaneesh et al. 2012 & 2.96 & 31.96 & 20.27 & 7.13 & 0.16 & 2.84 \\
\hline Parupeneus bifasciatus & Dhaneesh et al. 2012 & 5.56 & 31.51 & 20.67 & 6.88 & 0.17 & 3.00 \\
\hline Chelinus undulates & Dhaneesh et al. 2012 & 5.28 & 30.32 & 17.55 & 8.05 & 0.18 & 2.18 \\
\hline L. bohar & Dhaneesh et al. 2012 & 4.54 & 33.73 & 21.14 & 8.37 & 0.01 & 2.53 \\
\hline Hyporhamphus dussumieri & Dhaneesh et al. 2012 & 6.97 & 33.01 & 20.15 & 8.69 & 0.66 & 2.32 \\
\hline Lutianus agentimaculatus & Osman et al. 2007 & - & 27.43 & 7.51 & 8.18 & 0.34 & 2.17 \\
\hline Arius cumutranus & - & - & 48.58 & 10.81 & 20.06 & 1.05 & 4.13 \\
\hline Epinephelus sexfasciatus & Osman et al. 2007 & - & 41.55 & 8.81 & 17.19 & 5.24 & 2.11 \\
\hline Scomberomorus commersoni & Osman et al. 2007 & - & 37.69 & 9.44 & 17.34 & 4.38 & 2.83 \\
\hline Pristipomodes typus & Osman et al. 2007 & - & 39.72 & 10.02 & 16.44 & 3.72 & 2.68 \\
\hline Congresax talabon & Osman et al. 2007 & - & 54.36 & 19.61 & 16.48 & 4.52 & 2.27 \\
\hline Rastrelliger kanagurta & Osman et al. 2007 & - & 40.37 & 10.12 & 16.33 & 4.45 & 2.25 \\
\hline Psettodes crumei & Osman et al. 2007 & - & 51.29 & 16.08 & 19.25 & 4.15 & 2.63 \\
\hline Scolidon sorrakowah & Osman et al. 2007 & - & 50.84 & 7.13 & 14.75 & 13.41 & 1.68 \\
\hline Acanthurs nigrosis & Osman et al. 2007 & - & 50.75 & 10.72 & 21.4 & 5.21 & 2.00 \\
\hline Anadontostoma chacunda & Osman et al. 2007 & - & 53.11 & 14.89 & 19.46 & 1.87 & 1.95 \\
\hline Sciaena dussumieri & Osman et al. 2007 & - & 52.88 & 11.53 & 23.95 & 7.16 & 2.18 \\
\hline Gymnura spp. & Osman et al. 2001 & $1.95 \pm 0.14$ & 91.5 & 5.15 & 17.5 & 0.26 & - \\
\hline Eleutheronema tradactylum & Osman et al. 2001 & $2.24 \pm 0.20$ & 89.5 & 5.93 & 9.89 & 0.22 & - \\
\hline Plotosus spp. & Osman et al. 2001 & $2.79 \pm 0.37$ & 84.0 & 6.76 & 10.4 & 0.68 & - \\
\hline Parastromateus niger & Osman et al. 2001 & $2.79 \pm 0.25$ & 74.4 & 5.18 & 9.36 & 0.52 & - \\
\hline Pampus argenteus & Osman et al. 2001 & $2.91 \pm 0.11$ & 81.5 & 0.82 & 18.9 & 0.6 & - \\
\hline Clupea fimbriata & Osman et al. 2001 & $3.06 \pm 0.06$ & 76.9 & 4.35 & 17.3 & 0.19 & - \\
\hline Magalapsis cordyla & Osman et al. 2001 & $3.08 \pm 0.11$ & 86.9 & 5.76 & 28.6 & 0.45 & - \\
\hline Selarides leptolejus & Osman et al. 2001 & $5.77 \pm 0.52$ & 85.5 & 3.97 & 27.3 & 0.26 & - \\
\hline
\end{tabular}

studies suggest that EPA and DHA from fish n-3 enhance apoptosis in tumor cells (Ramesh et al. 1992, Madhavi and Das 1994, Ramesh and Das 1998, Das et al. 2002, Trombetta et al. 2007, Chapkin et al. 2008). The n-3 FAs are involved in tumor suppression by altering the phospholipid composition of cell membranes, and this affects multiple mechanisms of cancerous cells (Larsson et al. 2004, Chapkin et al. 2007). Several signaling pathways are now known by which n-3 FAs exert anti-tumor action by enhanced apoptosis and reduced proliferation. The n-3 FAs also interfere with cell cycle components, cell replication, and apoptosis-induced cell death (Field and Schley 2004, Serini et al. 2008). The findings of in-vitro research work carried out by various scientists on n-3 FAs to control the growth of cancerous cells are shown in Table 3. The in vivo studies also provided evidence to support the effect of omega-3 
Table 3

In Vitro studies of the effect of $\omega$-3 FAs on various cancer cell lines

\begin{tabular}{|c|c|c|c|c|c|}
\hline Author & Type of PUFA & Cell Line & Method/ Design & Result & Outcome \\
\hline $\begin{array}{l}\text { Pogash et } \\
\text { al. } 2014\end{array}$ & $\begin{array}{l}\text { DHA, 4-OH-DHA } \\
\text { and 4-OXO-DHA }\end{array}$ & $\begin{array}{l}\text { MDA MB-231, BT-549, } \\
\text { MCF-10F, bsMCF, trMCF } \\
\text { (triple-negative breast } \\
\text { cancer cell lines) and } \\
\text { T-47D, MCF-7 and } \\
\text { SK-BR-3 (luminal breast } \\
\text { cancer cell lines) }\end{array}$ & MTT assay for Cell viability & $\begin{array}{l}\downarrow \text { Growth of all basal and } \\
\text { two luminal (T-47D, } \\
\text { SK-BR-3) breast cancer cell } \\
\text { lines but MCF-7 showed } \\
\text { proliferation after DHA and } \\
\text { 4-OXO-DHA treatment. }\end{array}$ & $\begin{array}{l}\text { Anti-proliferative effect was } \\
\text { more evident on triple } \\
\text { negative breast cancer cell } \\
\text { lines for which currently no } \\
\text { targeted operation is } \\
\text { available. }\end{array}$ \\
\hline $\begin{array}{l}\text { Zajdel et al. } \\
2013\end{array}$ & EPA, DHA and AA & $\begin{array}{l}\text { A375, A2058, G361 } \\
\text { (melatonic melanoma cell } \\
\text { lines) and C32 (amelatonic } \\
\text { melanoma cell line) }\end{array}$ & $\begin{array}{l}\text { TOX-2 test for cytotoxicity } \\
\text { Aldehyde Site Detection Kit } \\
\text { for oxidative protein and } \\
\text { DNA modifications }\end{array}$ & $\begin{array}{l}\text { All FAs } \downarrow \text { proliferation in } \\
\text { A375, A2058, G361 at } 50 \\
\text { mM, followed by oxidative } \\
\text { protein and DNA damage at } \\
100 \mathrm{mM} \text {. } \\
\text { Only EPA and DHA } \downarrow \\
\text { proliferation in C32 at } 100 \\
\text { mM in which the effect of } \\
\text { DHA was more pronounced. }\end{array}$ & $\begin{array}{l}\text { Anti-proliferative action of } \\
\text { FAs depends on the type and } \\
\text { concentration of FAs and } \\
\text { type of melanoma cell lines } \\
\text { on which effect is being } \\
\text { observed. }\end{array}$ \\
\hline $\begin{array}{l}\text { Yang et al. } \\
2013\end{array}$ & EPA and DHA & $\begin{array}{l}\text { CSCs (colorectal cancer } \\
\text { stem cells) }\end{array}$ & $\begin{array}{l}\text { DNA fragmentation. } \\
\text { Annexin V-PI double } \\
\text { staining. } \\
\text { Flow cytometry for apoptosis } \\
\text { detection. } \\
\text { MTS assay for comparison of } \\
\text { sensitivity of spheroid cells. }\end{array}$ & $\begin{array}{l}\uparrow \text { Annexin } \mathrm{V} \text { expression. } \\
\uparrow \text { Apoptosis. } \\
\uparrow \text { Sensitivity of 5-Fu and } \\
\text { mitomycin } \mathrm{C} \text { to } \\
\text { chemotherapy. }\end{array}$ & $\begin{array}{l}\text { n-3 FAs act as direct } \\
\text { pro-apoptotic or } \\
\text { anti-proliferative agent for } \\
\text { cancer stem-like cells and } \\
\text { also as a potential adjuvant } \\
\text { for colorectal cancer therapy. }\end{array}$ \\
\hline $\begin{array}{l}\text { Fukui et al. } \\
2013\end{array}$ & EPA and DHA & $\begin{array}{l}\text { MIA-PaCa- } 2 \text { and Capan- } 2 \\
\text { (human pancreatic cancer } \\
\text { cell lines) }\end{array}$ & $\begin{array}{l}\text { MTT assay for Cell viability. } \\
\text { H2-DCF-DA for ROS } \\
\text { accumulation. } \\
\text { Western blot for gene } \\
\text { expression. } \\
\text { Monitoring LC3B- positively } \\
\text { staining cells for autophagy } \\
\text { assessment. } \\
\text { Transfection with Beclin } 1 \\
\text { siRNAs for autophagy } \\
\text { inhibition. }\end{array}$ & $\begin{array}{l}\downarrow \text { Cell viability. } \\
\uparrow \text { Intracellular ROS } \\
\text { accumulation. } \\
\uparrow \text { Caspase-8 dependent cell } \\
\text { death. } \\
\text { Autophagosome formation in } \\
\text { EPA supplemented cells. } \\
\text { Autophagy inhibition in } \\
\text { Beclin } 1 \text { siRNAs transfected } \\
\text { cells. }\end{array}$ & $\begin{array}{l}\text { EPA along with an } \\
\text { autophagy inhibitor can } \\
\text { increase the effectiveness of } \\
\text { EPA in inducing apoptotic } \\
\text { cell death in human } \\
\text { pancreatic cancer cells. }\end{array}$ \\
\hline $\begin{array}{l}\text { Dai et al. } \\
2013\end{array}$ & $\begin{array}{l}\text { LA, ALA, AA, EPA } \\
\text { and DHA }\end{array}$ & $\begin{array}{l}\text { MGC, SGC (gastric } \\
\text { carcinoma cell lines) and } \\
\text { GES1 (normal gastric cell } \\
\text { line) }\end{array}$ & $\begin{array}{l}\text { MTT assay for Cell viability. } \\
\text { Flow cytometry for } \\
\text { measuring the rate of } \\
\text { apoptosis. } \\
\text { GC for studying fatty acid } \\
\text { profile of cells. } \\
\text { DCFH-DA for ROS } \\
\text { generation. } \\
\text { ELISA test to determine } \\
\text { levels of lipoxin A4 } \\
\text { generated. }\end{array}$ & $\begin{array}{l}\downarrow \text { growth of MGC, SGC and } \\
\text { GES1 cell lines by all FAs, } \\
\text { indicating a very little } \\
\text { differential effect on normal } \\
\text { and tumor cells. } \\
\text { Lipid droplets accumulated } \\
\text { in cells treated with PUFAs. } \\
\uparrow \text { ROS generation in GES1 } \\
\text { cells by LA, ALA and EPA, } \\
\text { MGC cells by DHA, SGC } \\
\text { cells by all PUFAs. } \\
\text { AA produced highest level of } \\
\text { lipoxin A4 in MGC cells as } \\
\text { compared to GES1. }\end{array}$ & $\begin{array}{l}\text { Close sensitivity of normal } \\
\text { and cancer cells of stomach } \\
\text { to anticancer agents may } \\
\text { explain the reason of } \\
\text { significant side effects of } \\
\text { gastric cancer treatment, } \\
\text { since normal stomach cells } \\
\text { are affected. }\end{array}$ \\
\hline
\end{tabular}


Table 3

\begin{tabular}{|c|c|c|c|c|c|}
\hline Author & Type of PUFA & Cell Line & Method/ Design & Result & Outcome \\
\hline $\begin{array}{l}\text { Notarnicola } \\
\text { et al. } 2011\end{array}$ & $\mathrm{EPA}$ and $\mathrm{AA}$ & $\begin{array}{l}\text { HepG2 (human hepatoma } \\
\text { cell line) }\end{array}$ & $\begin{array}{l}\text { MTT assay for cell viability. } \\
\text { ELISA test for apoptosis } \\
\text { detection. } \\
\text { Real-time PCR to determine } \\
\text { levels of FAS and } \\
\text { HMG-CoAR mRNA in the } \\
\text { treated cells. }\end{array}$ & $\begin{array}{l}\text { EPA showed pro-apoptotic } \\
\text { effect and } \downarrow \text { cell growth at } \\
\text { lower doses }(1 \mu \mathrm{M} \text { and } 25 \\
\mu \mathrm{M} \text { respectively) while AA } \\
\text { require higher doses (100 } \\
\mu \mathrm{M}) \text { for the same. } \\
\downarrow \text { Gene expression of } \\
\text { HMG-CoAR and FAS (10 } \\
\mu \mathrm{M}) \text {. }\end{array}$ & $\begin{array}{l}\text { HepG2 cells were more } \\
\text { sensitive to EPA than AA, } \\
\text { determining more efficacy of } \\
\text { n-3 FAs as strong anticancer } \\
\text { agents. }\end{array}$ \\
\hline $\begin{array}{l}\text { Corsetto et } \\
\text { al. } 2011\end{array}$ & $\mathrm{EPA}, \mathrm{DHA}$, and $\mathrm{AA}$ & $\begin{array}{l}\text { MDA-MB-231 } \\
\text { (ER-negative) and MCF-7 } \\
\text { (ER-positive) breast cancer } \\
\text { cell lines. }\end{array}$ & $\begin{array}{l}\text { MTT assay for cell viability. } \\
\text { Western blot for Bcl2, } \\
\text { caspase-8, EGFR and } \\
\text { pEGFR HPLC/GC for } \\
\text { evaluation of FAs } \\
\text { incorporation into membrane } \\
\text { phospholipids. }\end{array}$ & $\begin{array}{l}\downarrow \text { Cell viability. } \\
\downarrow \text { Cell proliferation. } \\
\downarrow \text { Bcl2 and procaspase-8 } \\
\text { expression. } \\
\text { Activation of EGFR. FAs } \\
\text { incorporated with different } \\
\text { degrees of specificity, n-6 } \\
\text { FAs are influenced by n-3 } \\
\text { FAs and vice-versa. }\end{array}$ & $\begin{array}{l}\mathrm{n}-3 \text { FAs might induce } \\
\text { modifications in cell } \\
\text { membrane structure of } \\
\text { breast cancer cells by } \\
\text { increasing the degree of } \\
\text { unsaturation in FAs. }\end{array}$ \\
\hline $\begin{array}{l}\text { du } \\
\text { Toit-Kohn } \\
\text { et al. } 2009\end{array}$ & DHA & $\begin{array}{l}\mathrm{CaC}_{2} \text { (human } \\
\text { adenocarcinoma cell line), } \\
\text { NCM460 (normal colon } \\
\text { cell line). }\end{array}$ & $\begin{array}{l}\text { MTT assay for cell viability. } \\
\text { Western blot for analyzing } \\
\text { activity of p38 MAPK, ERK, } \\
\text { Akt and p53. } \\
\text { Specific protein inhibitors } \\
\text { and siRNA for analyzing } \\
\text { cross talk among signalling } \\
\text { pathways. }\end{array}$ & $\begin{array}{l}\downarrow \text { Cell viability in } \mathrm{CaC}_{2} \\
\text { cells. } \\
\uparrow \text { caspase-3 activation. } \\
\downarrow \text { Akt phosphorylation. } \\
\text { No effect on NCM460 cells. } \\
\text { siRNA experiments assessed } \\
\text { p38 MAPK's role in p53 } \\
\text { phosphorylation, associated } \\
\text { with DNA damage. }\end{array}$ & $\begin{array}{l}\text { DHA exerts cytotoxic/ } \\
\text { apoptotic effect specifically } \\
\text { on colon cancer cells without } \\
\text { affecting the normal cells, } \\
\text { suggesting the use of n-3 } \\
\text { FAs as tumor preventive } \\
\text { agent. }\end{array}$ \\
\hline $\begin{array}{l}\text { Heimli et } \\
\text { al. } 2002\end{array}$ & $\mathrm{EPA}$ & $\begin{array}{l}\text { Ramos (lymphoma cell } \\
\text { line). }\end{array}$ & $\begin{array}{l}{[3 \mathrm{H}] \text { thymidine and }} \\
{[3 \mathrm{H}] \text { valine incorporation for }} \\
\text { DNA and protein synthesis. } \\
\text { DNA staining with PI and } \\
\text { HO342 for cell viability } \\
\text { microscopic analysis. } \\
\text { Flow cytometry for cell cycle } \\
\text { analysis. } \\
\text { Annexin V-FITC binding } \\
\text { and PI staining for PS } \\
\text { translocation. } \\
\text { Colorimetric activation } \\
\text { assays for caspase-3, }-8 \text { and } \\
-9 \text { activity. }\end{array}$ & $\begin{array}{l}\downarrow \text { DNA and protein } \\
\text { synthesis. } \\
\text { PI stained cells indicate } \\
\text { leaky cell membrane. } \\
\text { HO342 stained cells indicate } \\
\text { intact or distorted cell } \\
\text { membrane. } \\
\text { No cell cycle arrest. } \\
\uparrow \text { Annexin V-FITC binding } \\
\text { and PS flipping followed by } \\
\text { PARP cleavage. } \\
\uparrow \text { caspase }-3,-8 \text { and }-9 \\
\text { activity. }\end{array}$ & $\begin{array}{l}\text { EPA in Ramos cells promote } \\
\text { cell death via intrinsic } \\
\text { apoptotic pathway and not } \\
\text { via cell cycle arrest. }\end{array}$ \\
\hline
\end{tabular}

Abbreviations: $\uparrow=$ Increase; $\downarrow=$ Decrease; AA = Arachidonic acid; ALA $=\alpha$-Linolenic acid; ANOVA = Analysis of variance; DCFH-DA = Dichloro-dihydro-fluorescein diacetate; DHA = Docosahexaenoic acid; EGFR = Epidermal growth factor receptor; ELISA = Enzyme-linked immunosorbent assay; EPA = Eicosapentaenoic acid; ER = Estrogen; ERK = Extracellular signal-regulated kinase; FAs $=$ Fatty acid synthase; GC = Gas chromatography; HMG-CoA-R = 3-Hydroxy-3-methyl-glutaryl-coenzyme A reductase; HPLC = High performance liquid chromatography; LA = Linoleic acid; $\mathrm{M}-\mathrm{APK}=$ Mitogen activated protein kinase; MTT = 3-(4,5-Dimethylthiazol-2-Yl)-2,5-diphenyltetrazolium bromide; OXO-DHA = $\alpha, \beta$-unsaturated keto-derivative of docosahexaenoic acid; PARP $=$ Poly-ADP-ribose polymerase PI = Propidium iodide; PS = Phosphatidylserine; PUFA = Poly unsaturated fatty acid; ROS = Reactive oxygen species; SiRNA = Small interfering RNA 
FAs on various types of tumor cells (Liu et al. 2000, Latham et al. 2001, Tsujita-Kyutoku et al. 2004, Wynter et al. 2004, Edwards et al. 2008).

\section{Changes induced by EPA-derived eicosanoids in cell membranes}

Dietary or supplemented n-3 FAs are incorporated into the phospholipids of tumor cell membranes and affect lipid packing, membrane permeability (Stillwell et al. 1997), lipid microdomains (Shaikh et al. 2001, Ma et al. 2004, Schley et al. 2005), and fusion (Ehringer et al. 1990), and they alter the signaling pathways of apoptosis (Chapkin et al. 2002, Ng et al. 2005, Schley et al. 2005). Diets rich in n-3 FAs partially replace $n-6$ FAs in cell membranes and lower the production of AA-derived prostaglandins (PGs), thromboxanes (TXs), and leukotrienes (LTs) (Crawford et al. 2000). Incorporated n-3 FAs (EPA and DHA) compete with n-6 FA (AA) to reduce the availability of n-6 FA for esterification at the sn-2 position of phospholipids (PLs) of cell membranes (Arterburn et al. 2006), which is followed by the hydrolytic release of EPA/DHA and AA from the membrane stores by the action of phospholipase $\mathrm{A}_{2}$ (Larsson et al. 2004). The released EPA/DHA and AA act as substrates for two different groups of enzymes, cyclooxygenases (COXs) and lipooxygenases (LOXs), and convert them into their metabolites known collectively as eicosanoids (20 carbon, short-lived) (Smith and Murphy 2002). The biosynthesis of eicosanoids from AA or EPA is catalyzed by COX enzymes (Hinz and Brune 2002). From three isoforms, COX-2 expression is induced by inflammatory and mitogenic stimuli (Warner and Mitchell 2004) that promote tumor, metastatic processes, the inhibition of apoptosis, and the formation of carcinogens and angiogenesis (Dannenberg et al. 2001). Ermert et al. (2003) reported that the increased expression of COX-2 is directly related to elevated levels of the downstream enzymes needed for the synthesis of prostanoids, which may increase products of AA metabolism. In in-vitro studies, n-3 FAs were found to play an active role in reducing the migration and invasiveness of $\mathrm{COX}-2$ to decrease the products of AA in brain-metastatic melanoma and prostate cancer cells (Denkins 2005, Brown et al. 2006). Earlier studies posited that the anti-cancer effect of n-3 FAs is mainly due to reductions in PGE2, but, later, Yang et al. (2013) and Funahashi et al. (2008) reported that PGE3 is also responsible for anti-proliferation in A549 and BxPC3 cancer cells, respectively, by inducing apoptosis. PGE3 also antagonized the pro-tumorigenic effect of PGE2 in HT-29 CRC cell transfection with EP4 in which the expression of COX-2 and other EP receptors were lacking, but the same result was not observed in HCA-7 CRC cells with high levels of endogenous PGE2 (Hawcroft et al. 2010). In RAW264.7 macrophage cells, cells supplemented with EPA showed increased amounts of PGE3 and PGD3 (EPA-derived COX metabolite) and decreased AA derived metabolites as compared to the control (Norris and Dennis 2012). Diets rich in EPA increased the formation of LTB5 and reduced the formation of LTB4 (an inducer of tumor cell adhesion) (Damtew and Spagnuolo 1997). EPA-derived LOX products are anti-inflammatory, and AA-derived LOX products are pro-inflammatory where inflammation was positively linked to cancer (Grivennikov et al. 2010), but lipoxins derived from AA are anti-inflammatory, which indicated the role of AA-derived eicosanoids in the anti-inflammatory response (Janakiram et al. 2011). Some AA-derived prostanoids, like PGI2 and 15d-PGJ2, were also found to be anti-mitotic and anti-metastatic (Honn et al. 1981, Bishop-Bailey et al.2002). COX and LOX activities on n-3 and n-6 FAs and the role of 2, 3, 4, and 5 series prostanoids are shown in Fig. 3.

\section{Alternation of key proteins and enzymes involved in apoptosis}

Multiple reports indicate that n-3 FAs can alter the expression or activity of a number of genes, signaling molecules and certain transcription factors associated with cell proliferation and apoptosis. The constitutive over-expression of Bcl-2, NFאB (Nuclear tran- 


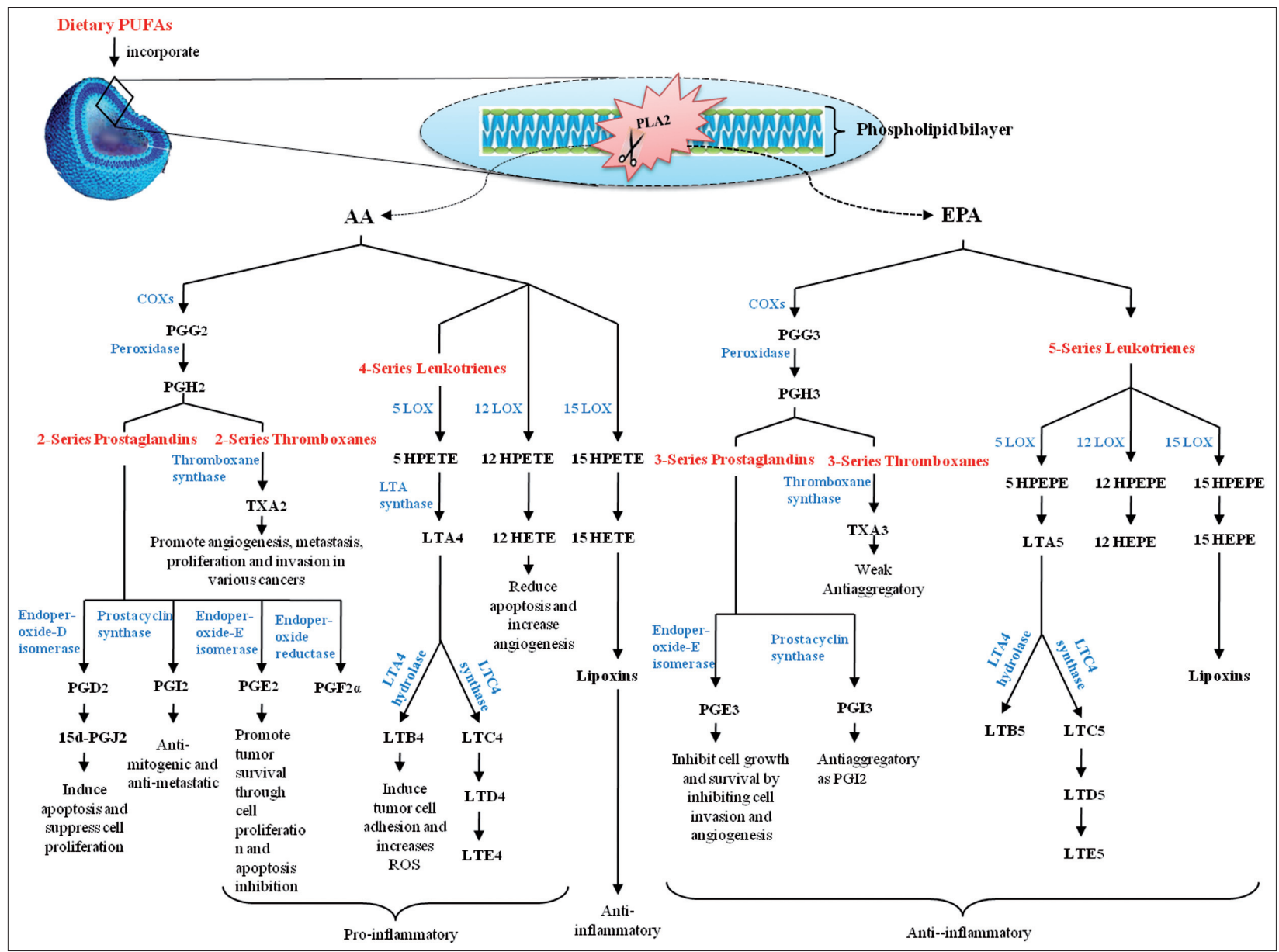

Figure 3. Competition between EPA and AA for COX and LOX for the formation of eicosanoids.

Abbreviations: PLA2 = phospholipase A2; AA = arachidonic acid; EPA = eicosapentaenoic acid; $\mathrm{COX}=$ cyclooxygenase; $\mathrm{LOX}=$ lipooxygenase; HPETE = hydroperoxyeicosatetraenoic acid; HPEPE = hydroperoxyeicosapentaenoic acid; HETE = hydroxyeicosatetraenoic acid; HEPE = hydroxyeicosapentaenoic acid; PG = prostaglandin; $L T=$ leukotriene; $\mathrm{TX}=$ thromboxane.

scription factor $\kappa \mathrm{B})$, Ras, and wnt $/ \beta$-catenin signaling molecules causes cell proliferation, and DHA has been shown to down-regulate their expression to induce apoptosis (Chiu and Wan 1999, Chen and Istfan 2000, Collet et al. 2001, Fuchs et al. 2005, Calviello et al. 2007, Song et al. 2011). Wild type p53, Bax, caspases-3, -8, and/or -9, and PPAR (peroxisome proliferator-activated receptor, a transcription factor) are known for their pro-apoptotic functions that induce apoptotic cell death. Different studies indicate that EPA/DHA up-regulate the expression of these apoptotic markers to activate the cell death pathway (Arita et al. 2001, Narayanan et al. 2001, Heimli et al. 2002, Jumb 2002, Fan et al. 2003, Chi et al. 2004, Okada and Mak 2004,
Hostetler 2005, Edwards et al. 2008, Fulda 2009). Details are in Fig. 4.

\section{Association between n-3 FAs and lipid peroxidation}

The supplementation of n-3 FAs in cancer cells appears to enhance lipid peroxidation and the generation of free radicals (Das 1991, Sangeetha and Das 1992), which reduce anti-oxidants and increase cytotoxicity in cancer cells (Padma and Das 1986). Free radicals generated can damage DNA and proteins and inactivate enzymes that induce cell death (Das 1999). Lipid peroxidation has been found to 


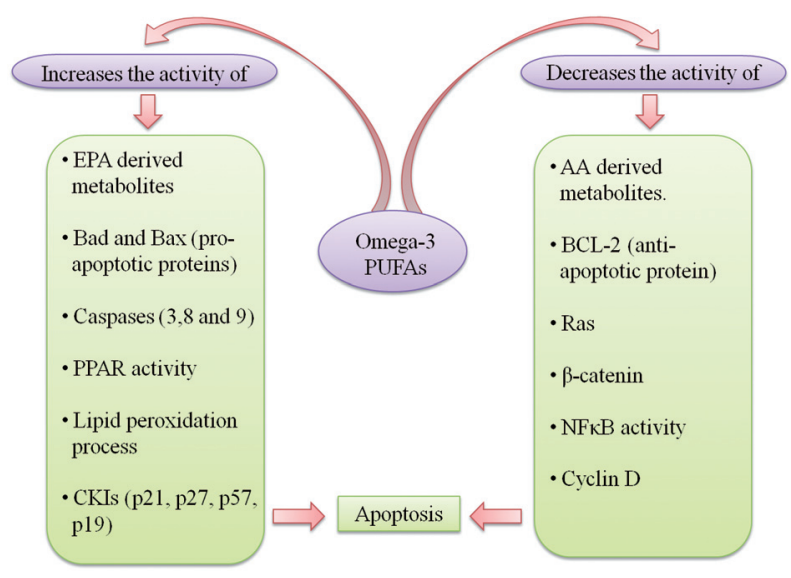

Figure 4. Model of signaling pathways of anti-cancerous actions of n-3 FAs.

inhibit the expression of Ras (Cheokin et al. 1997) and Bcl-2 oncogenes and enhances Fas expression that promotes apoptosis (Halder et al. 1995). Investigations have focused on the question of whether peroxidation products of EPA, DHA, and AA possess the ability to bind with Bcl-2 oncogenes, which leads to their inactivation by phosphorylation. Phosphorylated Bcl-2 increases lipid peroxide formation that ultimately leads to apoptosis (Halder et al. 1995). Fig. 5 shows the interactions among lipid peroxidation, n-3 FAs, Bcl-2 and Fas expression, and the induction of apoptosis. Szatrowski and Nathan (1991) reported that tumor tissues produce large amounts of ROS because of the insufficient blood flow as compared to surrounding normal tissues. Moreover, tumor cells treated with n-3 FAs show low levels of anti-oxidants that enhance the damaging actions of lipid peroxides that cause cytotoxicity (Padma and Das 1986, Kumar and Das 1995).

\section{Effect on cell cycle regulation}

Cell cycle is mediated by two types of control mechanisms, i.e., the coordinated interaction of cyclins with their respective cyclin dependent kinases (CDKs), and a set of checkpoints (Collins and Jacks 1997). The cyclin-CDK complexes are inactivated by cyclin-dependent kinase inhibitors (CKIs). These CKIs are categorized into two families: the Cip/Kip

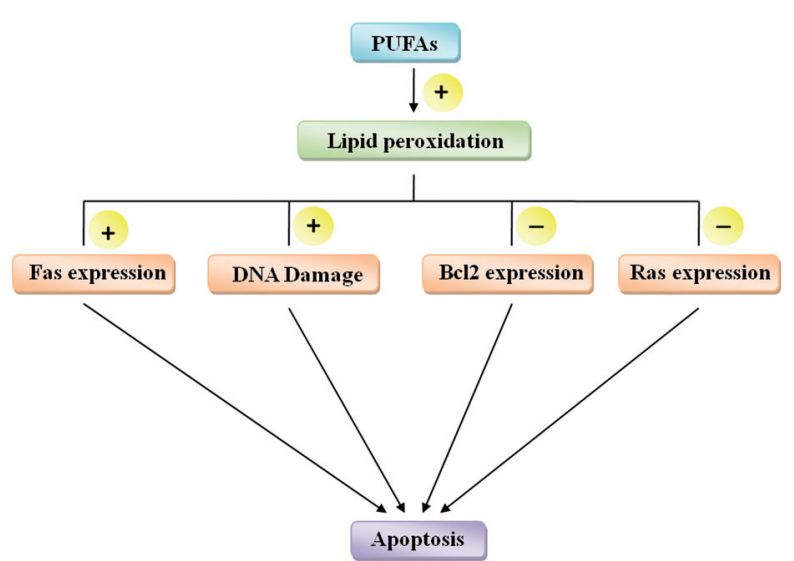

Figure 5. Schematic diagram of apoptosis induction by FAs through lipid peroxidation. + Indicate activation, - Indicate inhibition.

family (p21, p27 and p57), and the INK4 family (p15, p16, p18 and p19) (Morgan 1995, Sherr and Roberts 1999, Canepa et al. 2007). DHA-treated leukemic cells (Siddiqui et al. 2003) and colon and breast cancer cells (Danbara et al. 2004, Tsujita-Kyutoku et al. 2004) showed increases in p21 expression that arrested the cell cycle prior to the induction of apoptosis. These results were supported by a microarray study on CaCo- 2 colon cancer cells that showed increased p21, p27, p19, and p57 mRNA levels after treatment with DHA, which indicated the involvement of both CKI families in inhibiting cell cycle progression in the course of cancer inhibition (Narayanan et al. 2001).

The main checkpoints involved in cell cycle control are the G1/S and G2/M checkpoints (Foijer and Riele 2006). At the G1/S transition, cyclin D binds to $\mathrm{CDK} 4$ or CDK6 and phosphorylate Rb protein to release the transcription factor, E2F to transcribe the genes required for cell cycle progression and DNA synthesis (Kato et al. 1993, Delston and Harbour 2006). Omega-3 FAs have been shown to suppress the expression of cyclin $\mathrm{D}$ in various cancer cells such as those of the colon (Danbara et al. 2004, Narayanan et al. 2004, Jakobsen et al. 2008) breast (Tsujita-Kyutokuet al. 2004, Lu et al. 2010), and prostate (Lu et al. 2008). Moreover, n-3 FAs also repress the proliferation of cancer cells by mediating the G2/M transition. Barascu et al. (2006) reported 
that in MDA-MB-231 breast cancer cells, EPA and DHA markedly increased the duration of the G2/M phase with decreased activity of the cyclin B1-CDK1 complex, an essential regulator involved in the progression from G2 to M.

\section{n-3/n-6 ratio}

Omega-3 and n-6 FAs have been shown to manifest opposing roles in cancer progression. Excessive n-6 FAs, which are noted in today's western diets, have serious health implications, whereas, excess n-3 FAs exert suppressive effects. James and Cleland (1997) reported that drug therapy with the dietary intake of a higher $n-3 / n-6$ ratio (i.e., increased $n-3$ and decreased n-6 FAs) provides a suitable biochemical environment in which drugs show their potential effect. Mansara et al. (2015) showed the effect of low and high ratios of n-3/n-6 FAs in an in vitro study on cellular mechanisms in cancerous and non-cancerous cell lines. A high n-3/n-6 ratio was reported to decrease the cell viability of MCF7 and MDA-MB-231, while no reduction was observed in the cell viability of MCF10A. On the other hand, decreasing ratios of n-3/n-6 FAs were linked with a ratio-dependent decrease in cell viability in both breast cancer (MCF7 and MDA-MB-231) and a non-cancerous cell line (MCF10A).

\section{Future prospects}

Several mechanisms have been discussed by which n-3 FAs inhibit the development and progression of cancer. In this context, different ratios of n-3/n-6 FAs require special attention as is evident from the preceding discussion since limited studies have been carried out to scrutinize their effect on cancer cell lines. Therefore, more in vitro research needs to be undertaken that mimics the diet ratios of today's world, to evaluate the potential benefits and harmful effects of the FAs and to unravel the possible mechanisms and pathways responsible for such effects.
Studies have revealed that n-3 FAs can be used as effective adjuvants for chemotherapy (Vaughan et al. 2013), and that they also minimize secondary complications associated with cancer. When administered with n-3 FAs, the anticancer drug doxorubicin showed enhanced efficacy in its cytotoxic effect on various cancer cell lines such as the human breast cancer cell line, MDA-MB-231 (German et al. 1998), murine leukemia cells (Guffy et al. 1984), and small-cell lung carcinoma cell lines (Zijlstra et al. 1987). A synergistic interaction was observed by Siddiqui et al. (2011) between anticancer drugs and DHA along with increased drug transport particularly in cells that are normally resistant to these drugs. Similarly, cisplatin, paclitaxel, and docetaxel are some other curative anti-cancer drugs that are used to treat a wide range of cancers including head and neck, cervical, ovarian, and non-small-cell lung cancer (NSCLC), gastroesophageal, endometrium neoplasma, and bladder cancer (Wang and Lippard 2005, Nobili et al. 2009). These drugs also have certain serious side effects like neurotoxicity, nephrotoxicity, and emetogenesis (Wang and Lippard 2005, Hershman et al. 2011). Therefore, in future studies, these drugs should be tested in combination with n-3 FAs to help mitigate side effects and increase their efficacy.

Phytochemicals such as piperine (Siddiqui et al. 2017), naringenin (Ahamad et al. 2014), and curcumin (Iqbal et al. 2016) are also known to have anti-cancerous effects against human oral squamous carcinoma (KB cell line), human epidermoid carcinoma (A431 cell line), and human myeloid carcinoma (KCl-22cell line). Therefore, investigations on the use of EPA and DHA in combination with phytochemicals should be conducted with the aim of enhancing their cytotoxic effect on various cancer cell lines. Furthermore, antibodies like trastuzumab, a humanized anti-HER2 antibody, as specific carriers of n-3 FAs can also be used (Pegram et al. 2004) to target tumor cells in particular. This can improve the selectivity of n-3 FAs specifically against tumor cells. 


\section{Conclusion}

In light of the data reviewed, n-3 FAs can be considered as anti-proliferative and/or apoptosis-inducing agents for cancerous cells. They exert their anti-cancer effects by influencing multiple mechanisms involved in cancer development. These include changing the composition of cell membranes, blocking cell cycle, and altering the activity of key proteins, enzymes, and transcription factors involved in apoptosis. Some of the effects of n-3 FAs may not be directly related to fatty acid molecules themselves but rather to their metabolites such as eicosanoids and lipid peroxides. Research on the use of antibodies as specific carriers of n-3 FAs is needed to target tumor cells specifically. Research on the combination of n-3 FAs with anti-cancerous plant products, anti-tumor drugs, and increasing ratios of $n-3 / n-6$ FAs are considered to be important and can be employed for the prevention of cancer and/or as adjuvants to chemotherapy.

Acknowledgement. The authors are thankful to the head of the Department of Zoology, University of Lucknow for making available facilities and providing administrative support. Uttar Pradesh Council of Science and Technology (UP-CST), Lucknow is acknowledged for funding the study.

Author contributions. F.J. and P.A. collected, designed and analysed the data, and wrote the manuscript, M.A. analyzed the data, M.S. conceptualized, wrote and critically revised the manuscript.

\section{References}

Ahamad M.S., Siddiqui S., Jafri A., Ahmad S., Afzal M., Arshad M. 2014 - Induction of apoptosis and antiproliferative activity of naringenin in human epidermoid carcinoma cell through ROS generation and cell cycle arrest - PlOS One 9(10): e110003.

Almatsier S. 2003 - Basic Principles of Nutrition - Gramedia Pustaka Utama (in Indonesian).

Arita K., Kobuchi H., Utsumi T., Takehara Y., Akiyama J., Horton A.A., Utsumi K. 2001 - Mechanism of apoptosis in HL-60 cells induced by n-3 and n- 6 polyunsaturated fatty acids - Biochem. Pharmacol. 62: 821-828.
Arterburn L.M., Hall E.B., Oken H. 2006 - Distribution, interconversion, and dose response of n-3 fatty acids in humans - Am. J. Clin. Nutr. 83: 1467S-1476S.

Baracos V.E., Mazurak V.C., Ma D.W.L.2004 - n-3 Polyunsaturated fatty acids throughout the cancer trajectory: influence on disease incidence, progression, response to therapy and cancer-associated cachexia - Nutr. Res. Rev. 17: 177-192.

Barascu A., Besson P., Le Floch O., Bougnoux P., Jourdan M.L. 2006 - CDK1-cyclin B1 mediates the inhibition of proliferation induced by omega-3 fatty acids in MDA-MB-231 breast cancer cells - Int. J. Biochem. Cell Biol. 38: 196-208.

Bishop-Bailey D., Calatayud S., Warner T.D., Hla T., Mitchell J.A. 2002 - Prostaglandins and the regulation of tumor growth - J. Environ. Pathol. Toxicol. Oncol. 21: 93-101.

Brett M.T., Müller-Navarra D.C. 1997 - The role of highly unsaturated fatty acids in aquatic foodweb processes Freshw. Biol. 38: 483-499.

Brown M.D., Hart C.A., Gazi E., Bagley S., Clarke N.W. 2006 - Promotion of prostatic metastatic migration towards human bone marrow stoma by Omega 6 and its inhibition by Omega 3 PUFAs - Brit. J. Cancer 94: 842-853.

Calviello G., Resci F., Serini S., Piccioni E., Toesca A., Boninsegna A., Monego G., Ranelletti F.O., Palozza P. 2007 - Docosahexaenoic acid induces proteasome-dependent degradation of beta-catenin, $\underline{\text { down-regulation of survivin and apoptosis in human }}$ colorectal cancer cells not expressing COX-2 Carcinogenesis 28: $1202-1209$.

Canepa E.T., Scassa M.E., Ceruti J.M., Marazita M.C., Carcagno A.L., Sirkin P.F., Ogara M.F. 2007 - INK4 proteins, a family of mammalian CDK inhibitors with novel biological functions - IUBMB Life 59: 419-426.

Cantrill R.C., Ells G.W., De Marco A.C., Horrobin D.F. 1997 Mechanism of the selective cytotoxic actions of certain essential fatty acids - In: Eicosanoids and Other Bioactive Lipids in Cancer, Inflammation, and Radiation Injury 2. Part A (Eds) K.V. Honn, S. Nigam, L.J. Marnett, Springer Science+Businnes Media: 539-544.

Çelik M., Diler A., Küçükgülmez A. 2005 - A comparison of the proximate compositions and fatty acid profiles of zander (Sander lucioperca) from two different regions and climatic conditions - Food Chem. 92: 637-641.

Cengiz E.I., Ünlü E., Başhan M. 2010 - Fatty acid composition of total lipids in muscle tissues of nine freshwater fish from the River Tigris (Turkey) - Turk. J. Biol. 34: 433-438.

Chapkin R.S., Hong M.Y., Fan Y.Y., Davidson L.A., Sanders L.M., Henderson C.E., Barhoumi R., Burghardt R.C., Turner N.D., Lupton J.R. 2002 - Dietary n-3 PUFA alter colonocyte mitochondrial membrane composition and function - Lipids 37: 193-199. 
Chapkin R.S., Mc Murray D.N., Lupton J.R. 2007 - $\underline{\text { Colon }}$ cancer, fatty acids and anti-inflammatory compounds Curr. Opin. Gastroenterol. 23: 48-54.

Chapkin R.S., Seo J., Mc Murray, Lupton J.R. 2008 - Mechanisms by which docosahexaenoic acid and related fatty acids reduce colon cancer risk and inflammatory disorders of the intestine - Chem. Phys. Lipids 153: 14-23.

Chen Z.Y., Istfan N.W. 2000 - Docosahexaenoic acid is a potent inducer of apoptosis in HT-29 colon cancer cells - Prostaglandins Leukot. Essent. Fatty Acids 63: 301-308.

Cheokin R.S., Jiang Y.H., Davidson L., A., Lupton J.R. 1997 Modulation of intra cellular second messengers by dietary fat during colonic tumour development - Adv. Exp. Med. Biol. 422: 85-96.

Chi T.Y., Chen G.G., Lai P.B. 2004 - Eicosapentaenoic acid induces Fas-mediated apoptosis through a p53-dependent pathway in hepatoma cells - Cancer J.10: 190-200.

Chiu L.C., Wan J.M. 1999 - Induction of apoptosis in HL-60 cells by eicosapentaenoic acid (EPA) is associated with downregulation of bcl-2 expression - Cancer Lett. 145: 17-27.

Collett E.D., Davidson L.A., Fan Y.Y., Lupton J.R., Chapkin R.S. $2001-n-6$ and n-3 polyunsaturated fatty acids differentially modulate oncogenic Ras activation in colonocytes - Am. J. Physiol. Cell Physiol. 280: C1066-C1075.

Collins K., Jacks T., Pavletich N.P. 1997 - The cell cycle and cancer - Proc. Natl. Acad. Sci. USA 94: 2776-2778.

Colomer R., Moreno-Nogueira J.M., Garcia-Luna P.P., García-Peris P., García-de-Lorenzo A., Zarazaga A., Quecedo L., del Llano J., Usán L., Casimiro C. 2007 - n-3 fatty acids, cancer and cachexia: a systematic review of the literature - Brit. J. Nutr. 97: 823-831.

Corsetto P.A., Montorfano G.M., Zava S., Jovenitti I.E., Cremona A., Berra B., Rizzo A.M. 2011 - Effects of n-3 PUFAs on Breast Cancer Cells through their Incorporation in Plasma Membrane - Lipids Health Dis. 10: 73.

Crawford M., Galli C., Visioli F., Renaud S., Simopoulos A.P., Spector A.A. 2000 - Role of plant-derived omega-3 fatty acids in human nutrition - Ann. Nutr. Metab. 44: 263-265.

Crawford M.A. 1993 - The role of essential fatty acids in neural development: implications for perinatal nutrition Am. J. Clin. Nutr. 57: 703S-710S.

Dai J., Shen J., Pan W., Shen S., Das U.N. 2013 - Effects of Polyunsaturated Fatty Acids on the Growth of Gastric Cancer Cells in-vitro - Lipids Health Dis. 12: 71.

Damtew B., Spagnuolo P.J. 1997 - Tumor cell-endothelial cell interactions: evidence for roles for lipoxygenase products of arachidonic acid in metastasis Prostaglandins Leukot. Essent. Fatty Acids 56: 295-300.
Danbara N., Yuri T., Tsujita-Kyutoku M., Sato M., Senzaki H., Takada H., Hada T., Miyazawa T., Okazaki K., Tsubura A. 2004 - Conjugated docosahexaenoic acid is a potent inducer of cell cycle arrest and apoptosis and inhibits growth of colo 201 human colon cancer cells - Nutr. Cancer 50: 71-79.

Dannenberg A.J., Altorki N.K., Boyle J.O., Dang C., Howe L.R., Weksler B.B., Subbaramaiah K. 2001 Cyclooxygenase-2: a pharmacological target for the prevention of cancer - Lancet. Oncol. 2: 544-551.

Das U.N. 1991 - Tumoricidal action of cis-unsaturated fatty acids and its relationship to free radicals and lipid peroxidation - Cancer Lett. 50: 235-243.

Das U.N. 1999 - Essential fatty acids, lipid peroxidation and apoptosis - Prostaglandins Leukot. Essent. Fatty Acids 61: 157-163.

Das U.N., Swamy S.M.K., Tan B.K.H. 2002 - Mechanisms by which docosahexaenoic acid and related fatty acids reduce colon cancer risk and inflammatory disorders of the intestine - Nutrition 18: 348-350.

Delston R.B., Harbour J.W. 2006 - $\underline{\mathrm{Rb}}$ at the interface between cell cycle andapoptotic decisions - Curr. Mol. Med. 6: 713-718.

Denkins Y., Kempf D., Ferniz M., Nileshwar S., Marchetti D. 2005 - Role of omega-3 polyunsaturated fatty acids on cyclooxygenase- 2 metabolism in brain-metastatic melanoma - J. Lipid Res. 46: 1278-1284.

Dhaneesh K.V., Noushad K.M., Ajith T.T. 2012 - Nutritional evaluation of commercially important fish species of Lakshadweep Archipelago, India - PLOS One 7: e45439.

Domingo J.L. 2007 - Omega-3 Fatty Acids and the Benefits of Fish Consumption: Is all that Glitters Gold? - Environ. Int. 33: 993-998.

Edwards I.J., Sun H., Hu Y., Berquin I.M., O’Flaherty J.T., Cline J.M., Rudel L.L., Chen Y.Q. 2008 - In vivo and in vitro regulation of syndecan-1 in prostate cells by $n-3$ polyunsaturated fatty acids - J. Biol. Chem. 283: 18441-18449.

Ehringer W., Belcher D., Wassall S.R., Stillwell W. 1990 A comparison of the effects of linolenic (18:3 $\Omega 3)$ and

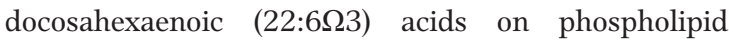
bilayers - Chem. Phys. Lipids 54: 79-88.

Ermert L., Dierkes C., Ermert M. 2003 Immunohistochemical expression of cyclooxygenase isoenzymes and downstream enzymes in human lung tumors - Clin. Cancer Res. 91: 1604-1610.

Fan Y.Y., Spencer T.E., Wang N., Moyer M.P., Chapkin R.S. 2003 - Chemopreventive n-3 fatty acids activate RXR-alpha in colonocytes - Carcinogenesis 24: 1541-1548.

Field C.J., Schley P.D. 2004 - Evidence for potential mechanisms for the effect of conjugated linoleic acid on tumor metabolism and immune function: lessons from n-3 fatty acids - Am. J. Clin. Nutr.79: 1190-1198. 
Foijer F., Riele H.T. 2006 - Check, double check: the G2 barrier to cancer - Cell Cycle 5: 831-836.

Fuchs S.Y., Ougolkov A.V., Spiegelman V.S., Minamoto T. 2005 - Oncogenic beta-catenin signalling networks in colorectal cancer - Cell Cycle 4: 1522-1539.

Fukui M., Kang K.S., Okada K., Zhu B.T. 2013 - EPA, an Omega-3 Fatty Acid, Induces Apoptosis in Human Pancreatic Cancer Cells: Role of ROS Accumulation, Caspase-8 Activation and Autophagy Induction - J. Cell. Biochem. 114: 192-203.

Fulda S. 2009 - Tumor resistance to apoptosis - Int. J. Cancer 124: $511-515$.

Funahashi H., Satake M., Hasan S., Sawai H., Newman R.A., Reber H.A., Hines O.J., Eibl G. 2008 - Opposing effects of n-6 and n-3 polyunsaturated fatty acids on pancreatic cancer growth - Pancreas 36: 353-362.

Gerber M. 2012 - Omega-3 fatty acids and cancers: a systematic update review of epidemiological studies - Brit. J. Nutr. 107: S228-S239.

German E., Chajčs V., Cognault S., Lhuillery C., Bougnoux P. 1998 - Enhancement of doxorubicin cytotoxicity by polyunsaturated fatty acids in the human breast tumor cell line MDA-MB-231: relationship to lipid peroxidation Int. J. Cancer 75: 578-583

Griffiths G., Jones H.E., Eaton C.L., Stobart A.K. 1997 - Effect of $n-6$ polyunsaturated fatty acids on growth and lipid composition of neoplastic and non-neoplastic canine prostate epithelial cell cultures - The Prostate 31: 29-36.

Grivennikov S.I., Greten F.R., Karin M. 2010 - Immunity, inflammation and cancer - Cell 140: 883-899.

Guffy M.M., North J.A., Burns C.P. 1984 - Effect of cellular fatty acid alteration on adriamycin sensitivity in cultured L1210 murine leukemia cells - Cancer Res. 44: 1863-1866

Guil-Guerrero J.L., Lopez-Martinez J.C., Rincon-Cervera M.A.. Campra-Madrid P. 2007 - One step extraction and concentration of polyunsaturated fatty acids from fish liver - J. Am. Oil Chem. Soc. 84: 357-361.

Halder S., Jena N., Croce C.M. 1995 - Inactivation of BCL-2 by phosphorylation - Proc. Natl. Acad. Sci. USA 92: 4507-4511.

Haliloğlu H.İ., Bayır A., Sirkecioğlu A.N., Aras N.M. Atamanalp M. 2004 - Comparison of fatty acid composition in some tissues of rainbow trout (Oncorhynchus mykiss) living in seawater and freshwater - Food Chem. 86: 55-59.

Hanahan D., Weinberg R.A. 2000 - The Hallmarks of cancer Review - 100: 57-70.

Hawcroft G., Loadman P.M., Belluzzi A., Hull M.A. 2010 Effect of eicosapentaenoic acid on E-type prostaglandin synthesis and EP4 receptor signalling in human colorectal cancer cells - Neoplasia 12: 618-627.

Heimli H., Giske C., Naderi S., Drevon C.A., Hollung K. 2002 - Eicosapentaenoic acid promotes apoptosis in Ramos cells via activation of caspase-3 and -9 - Lipids 37: 797-802.

Hershman D.L., Weimer L.H., Wang A., Kranwinkel G., Brafman L., Fuentes D., Awad D., Crew K.D. 2011 Association between patient reported outcomes and quantitative sensory tests for measuring long-term neurotoxicity in breast cancer survivors treated with adjuvant paclitaxel chemotherapy - Breast Cancer Res. Treat. 125: 767-774.

Higashi S., Murata N. 1993 - An in-vivo Study of Substrate Specificities of Acyl-Lipid Desaturases and Acyl Transferases in Lipid Synthesis in Synechocystis PCC6803Plant Phyiol. 102: 1275-1278.

Hinz B., Brune K. 2002 - Cyclooxygenase: 2-10 years later J. Pharmacol. Exp. Ther. 300: 367-375.

Homayooni B., Sahari M.A., Barzegar M. 2014 - Concentrations of omega-3 fatty acids from rainbow sardine fish oil by various methods - Int. Food Res. J. 21: 743-748.

Honn K.V., Cicone B., Skoff A. 1981 - Prostacyclin: a potent anti-metastatic agent -Science 212: 1270-1272.

Hostetler H.A., Petrescu A.D., Kier A.B., Schroeder F. 2005 Peroxisome proliferator-activated receptor alpha interacts with high affinity and is conformationally responsive to endogenous ligands - J. Biol. Chem. 280: 18667-18682.

Huynh M.D., Kitts D.D., Hu C., Trites A.W. 2007 - Comparison of fatty acid profiles of spawning and non-spawning Pacific herring, Clupea harenguspallasi - Comp. Biochem. Physiol. B Biochem. Mol. Biol. 146: 504-511.

Iqbal B., Ghildiyal A., Sahabjada S.S., Arshad M., Mahdi A.A., Tiwari S. 2016 - Antiproliferative and apoptotic effect of curcumin and TRAIL (TNF related apoptosis inducing ligand) in chronic myeloid leukaemic cells - J. Clin. Diagn. Res. 10(4): XC01-XC05.

Jabeen F., Chaudhry A.S. 2011 - Chemical compositions and fatty acid profiles of three freshwater fish species - Food Chem. 125: 991-996.

Jakhar J.K., Pal A.K., Reddy A.D., Sahu N.P., Venkateshwarlu G., Vardia H.K. 2012 - Fatty Acids Composition of Some selected Indian Fishes - Afr. J. Basic Appl. Sci. 4: 155-160.

Jakobsen C.H , Storvold G.L , Bremseth H., Follestad T., Sand K., Mack M., Olsen K.S., Lundemo A.G., Iversen J.G., Krokan H.E,. Schønberg S.A. 2008 - DHA induces ER stress and growth arrest in human colon cancer cells: associations with cholesterol and calcium homeostasis J. Lipid Res. 49: 2089-2100.

James M.J., Cleland L.G. 1997 - Dietary n-3 fatty acids and therapy for rheumatoid arthritis - Semin. Arthritis Rheum. 27: 85-97.

Janakiram N.B., Mohammed A., Rao C.V. 2011 - Role of lipoxins, resolvins and other bioactive lipids in colon and pancreatic cancer - Cancer Metastasis Rev. 30: 507-523. 
Johnson S., Saikia N., Mathur H.B., Agarwal H.C. 2009 Fatty acid profile of edible oils and fats in India - Centre for Science and Environment, New Delhi: 3-31.

Jump D.B. 2002 - The biochemistry of n-3 polyunsaturated fatty acids - J. Biol. Chem. 277: 8755-8758.

Kato J., Matsushime H., Hiebert S.W., Ewen M.E., Sherr C.J. 1993 - Direct binding of cyclin D to the retinoblastoma gene product $(\mathrm{pRb})$ and $\mathrm{pRb}$ phosphorylation by the cyclin D-dependent kinase CDK4 - Genes Dev. 7: 331-342.

Kinsella J.E. 1988 - Fish and sea foods: nutritional implication and quality issues - Food Technol. 51: 46-50.

Kumar S.G., Das U.N. 1995 - Free radical dependent suppression of growth of mouse myelomia cells by alpha-linolenic and eicosapentaenoic acid in vitro - Cancer Lett. 92: 27-38.

Larsson S.C., Kumlin M., Ingelman-Sundberg M., Wolk A. 2004 - Dietary long-chain n-3 fatty acids for the prevention of cancer: a review of potential mechanisms - Am. J. Clin. Nutr. 79: 935- 945.

Latham P., Lund E.K., Brown J.C., Johnson I.T. 2001 - Effects of cellular redox balance on induction of apoptosis by eicosapentaenoic acid in HT29 colorectal adenocarcinoma cells and rat colon in vivo - Gut. 49: 97-105.

Liu X.H., Kirschenbaum A., Yao S., Lee R., Holland J.F., Levine A.C. 2000 - Inhibition of cyclooxygenase-2 suppresses angiogenesis and the growth of prostate cancer in vivo - J. Urol. 164: 820-825.

Ljubojevic D., Trbovic D., Lujic J., Bjelic-Cabrilo O., Kostic D., Novakov N., Cirkovic M. 2013 - Fatty acid composition of fishes from inland waters - Bulg. J. Agric. Sci. 19: 62-71.

Lu I.F., Hasio A.C., Hu M.C., Yang F.M., Su H.M. 2010 Docosahexaenoic acid induces proteasome-dependent degradation of estrogen receptor alpha and inhibits the downstream signalling target in MCF-7 breast cancer cells - J. Nutr. Biochem. 21: 512-517.

Lu. Y., Nie. D., Witt W.T., Chen Q., Shen M., Xie H., Lai L., Dai Y., Zhang J. 2008 - Expression of the fat-1 gene diminishes prostate cancer growth in-vivo through enhancing apoptosis and inhibiting GSK-3 beta phosphorylation - Mol. Cancer Ther. 7: 3203-3211.

Łuczyńska J., Borejszo Z., Łuczyński M.J. 2008 - The composition of fatty acids in muscles of six freshwater fish species from the Mazurian Great Lakes (Northeastern Poland) - Arch. Pol. Fish. 16: 167-178.

Ma D.W., Seo J., Switzer K.C., Fan Y.Y., McMurray D.N., Lupton J.R., Chapkin R.S. 2004 - n-3 PUFA and membrane microdomains: a new frontier in bioactive lipid research - J. Nutr. Biochem.15: 700-706.

Madhavi N., Das U.N. 1994 - Effect of n-6 and n-3 fatty acids on the survival of Vincristine sensitive and resistant human cervical carcinoma cells in vitro - Cancer Lett. 84: 31-41.

Mahmoud B.S., Kawai Y., Yamazaki K., Miyashita K., Suzuki T. 2007 - Effect of treatment with electrolysed $\mathrm{NaCl}$ solutions and essential oil compounds on the proximate composition, amino acid and fatty acid composition of carp fillets - Food Chem. 101: 1492-1498.

Mansara P.P., Deshpande R.A., Vaidya M.M., Kaul-Ghanekar R. 2015 - Differential Ratios of Omega Fatty Acids (AA/EPA+DHA) Modulate Growth, Lipid Peroxidation and Expression of Tumor Regulatory MARBPs in Breast Cancer Cell Lines MCF7 and MDA-MB-231 - PLOS One 10: e0136542.

Morgan D.O. 1995 - Principles of CDK regulation - Nature 374: 134 .

Napier J.A. 2002 - Plumbing the depths of PUFA biosynthesis: a novel polyketide synthase-like pathway from marine organisms - Trends Plant Sci. 7: 51-54.

Narayanan B.A., Narayanan N.K., Desai D., Pittman B., Reddy B.S. 2004 - Effects of a combination of docosahexaenoic acid and 1,4-phenylene bis(methylene) selenocyanate on cyclooxygenase 2 , inducible nitric oxide synthase and beta-catenin pathways in colon cancer cells Carcinogenesis 25: 2443-2449.

Narayanan B.A., Narayanan N.K., Reddy B.S. 2001 Docosahexaenoic acid regulated genes and transcription factors inducing apoptosis in human colon cancer cells Int. J. Oncol. 19: 1255-1262.

Ng Y., Barhoumi R.,Tjalkens R.B., Fan Y.Y., Kolar S., Wang N., Lupton J.R., Chapkin R.S. 2005 - The role of docosahexaenoic acid in mediating mitochondrial membrane lipid oxidation and apoptosis in colonocytes Carcinogenesis 26: 1914-1921.

Nobili S., Lippi D., Witort E., Donnini M., Bausi L., Mini E., Capaccioli S. 2009 - Natural compounds for cancer treatment and prevention - Pharmacol. Res. 59: 365-378.

Norris P.C., Dennis E.A. 2012. - Omega-3 fatty acids cause dramatic changes in TLR4 and purinergic eicosanoid signalling - Proc. Natl. Acad. Sci. USA 109: 8517-8522.

Notarnicola M., Messa M., Refolo M.G., Tunio V., Miccolis A., Caruso M.G. 2011 - Polyunsaturated Fatty Acids Reduce Fatty Acid Synthase and Hydroxy-Methyl-Glutaryl CoA-Reductase Gene Expression and Promote Apoptosis in HepG2 Cell Line - Lipids Health Dis. 10: 10.

Okada H., Mak T.W. 2004 - Pathways of apoptotic and non-apoptotic death in tumour cells - Nat. Rev. Cancer 4: 592-603.

Omar M.N., Ahlam N.S., Yusoff M., Zainuddin N.A., Yunus K. 2010 - $\omega$-Fatty acids from Malaysian giant snakehead (Channamicropeltes) fish oil - Orient J. Chem. 26: 01-04.

Osman F., Jaswir I., Khaza'ai H., Hashim R. 2007 - Fatty acid profiles of fin fish in Langwani Island Malaysia - J. Oleo Sci. 56: 107-113. 
Osman H., Suriah A.R., Law E.C. 2001 - Fatty acid composition and cholesterol content of selected marine fish in Malaysian waters - Food Chem. 73: 55-60.

Padma M., Das U.N. 1986 - Effect of cis unsaturated fatty acids on cellular antioxidant stress in macrophage tumour (AK-5) cells in vitro - Cancer Lett. 109: 63-75.

Pegram M.D., Konecny G.E., O’Callaghan C., Beryt M., Pietras R., Slamon D.J. 2004 - Rational combinations of trastuzumab with chemotherapeutic drugs used in the treatment of breast cancer - J. Natl. Cancer Inst. 96: 739-749.

Pogash T.J., El-Bayoumy K., Amin S., Gowda K., de Cicco R.L.,Barton M., Su Y., Russo I.H., Himmelberger J.A., Slifker M., Manni A. 2014 - Oxidized Derivative of Docosahexaenoic Acid Preferentially Inhibit Cell Proliferation in Triple Negative Over Luminal Breast Cancer Cells - In Vitro Cell. Dev. Biol.-Anim. 51: 121-127.

Rahimabadi E.Z., Mirdar J., Elahi M.Y., Arshadi M.R. 2009 The lipid quality assessment of Shizothoraxzarudnyi and Schizocyprisaltidorsalis by fatty acid analysis - Pak. J. Biol. Sci. 12: 1090-1093.

Rahman S.A., Huah T.S., Nassan O., Daud N.M. 1995- Fatty acid composition of some Malaysian freshwater fish Food Chem. 54: 45-49.

Ramesh G., Das U.N. 1998 - Effect of cis-unsaturated fatty acids on Meth-A ascetic tumour cells in vitro and in vivo - Cancer Lett. 123: 207-214.

Ramesh G., Das U.N., Koratkar R., Padma M., Sagar P.S. 1992 - Effect of essential fatty acids on tumor cells Nutrition 8: 343-347.

Ratkowsky D.A., Olley J., Jayasinghe J.A.G., Wijesundara R.C. 1996 - A consistent correlation between monounsaturated and $n-3$ polyunsaturated fatty acids in fresh of fish caught at different latitudes - ASEAN Food J. 11: 43-47.

Roynette C.E., Calder P., Dupertuis Y.M., Pichard C. 2004 n-3 polyunsaturated fatty acids and colon cancer prevention - Clin. Nutr. 23: 139-151.

Sahena F., Zaidul I.S.M., Jinap S., Saari N., Jahurul H.A., Abbas K.A., Norulaini N.A. 2009 - PUFAs in Fish: Extraction, Fractionation, Importance in Health - Compr. Rev. Food Sci. Food Saf. 8: 59-74.

Saito H., Yamashiro R., Alasalvar C., Konno T. 1999 - Influence of diet on fatty acids of three subtropical fish, subfamily Caesioninae (Caesiodia gramma and C. tile) and family Siganidae (Siganus canaliculatus) - Lipid 34: 1073-1081.

Sangeetha P., Das U.N. 1992 - Cytotoxic action of cis-unsaturated fatty acids on human cervical carcinoma (HeLa) cells: relationship to free radicals and lipid peroxidation and its modulation by calmodulin antagonists - Cancer Lett. 63: 189-198.

Schley P.D., Jijon H.B., Robinson L.E., Field C.J. 2005 Mechanisms of omega-3 fatty acid-induced growth inhibition in MDA-MB-231 human breast cancer cells Breast Cancer Res. Treat. 92: 187-195.

Schmitz G., Ecker J. 2008 - The opposing effects of n-3 and n-6 fatty acids -Prog. Lipid Res. 47: 147-155.

Serini S., Trombino S., Oliva F., Piccioni E., Monego G., Resci F., Boninsegna A., Picci N., Ranelletti F.O., Calviello G. 2008 - Docosahexaenoic acid induces apoptosis in lung cancer cells by increasing MKP-1 and down-regulating p-ERK1/2 and p-p38 expression - Apoptosis 13: 1172-1183.

Shaikh S.R., Dumaual A.C., Jenski LJ., Stillwell W. 2001 Lipid phase separation in phospholipid bilayers and monolayers modeling the plasma membrane - Biochem. Biophys. Acta-Biomembr. 1512: 317-328.

Sharma P., Kumer V., Sinha A.K., Ranjan J., Kithsiri H.M.P., Venkateshwarlu G. 2010 - Comparative fatty acid profiles of wild and farmed tropical freshwater fish rohu (Labeo rohita) - Fish Physiol. Biochem. 36: 411-417.

Sherr C.J., Roberts J.M. 1999 - CDK inhibitors: positive and negative regulators of G1-phase progression - Genes Dev. 13: 1501-1512.

Siddiqui R.A., Harvey K.A., Xu Z., Bammerlin E.M., Walker C., Altenburg J.D. 2011 - Docosahexaenoic acid: a natural powerful adjuvant that improves efficacy for anticancer treatment with no adverse effects - Biofactors 37: 399-412.

Siddiqui R.A., Jenski L.J., Harvey K.A., Wiesehan J.D., Stillwell W., Zaloga G.P. 2003 - Cell-cycle arrest in Jurkat leukaemic cells: a possible role for docosahexaenoic acid - Biochem. J. 371: 621-629.

Siddiqui S., Ahamad M.S., Jafri A., Afzal M., Arshad M. 2017 - Piperine triggers apoptosis of human oral squamous carcinoma through cell cycle arrest and mitochondrial oxidative stress - Nutr. Cancer 69: 791-799.

Simopoulos A.P. 2002 - Omega-3 fatty acids in inflammation and autoimmune diseases - J. Am. Coll. Nutr. 21: 495-505.

Simopoulos A.P. 2002 - The importance of the ratio of omega-6/omega-3 essential fatty acids - Biomed. Pharmacother. 56: 365-379.

Smith W., Murphy R. 2002 - The eicosanoids: cyclooxygenase, lipoxygenase and epoxygenase pathways - In: Biochemistry of Lipids, Lipoproteins and Membranes (Eds) D.E. Vance, J.E. Vance, Elsevier, Amsterdam: 341-372.

Solomon L.Z., Jennings A.M., Sharpe P., Cooper A.J., Birch B.R. 1998 - Intravesical chemotherapy with gamma linolenic acid becomes a realistic prospect in serum-free applications: In vitro cytotoxicity and systemic absorption studies - J. Urol. 160: 2280-2283.

Song K.S., Jing K., Kim J.S., Yun E.J., Shin S., Seo K.S., Park J.H., Heo J.Y., Kang J.X., Suh K.S., Wu T. 2011 Omega-3- polyunsaturated fatty acids suppress pancreatic cancer cell growth in vitro and in vivo via 
downregulation of Wnt/Beta-catenin signalling Pancreatology 11: 574-584.

Stancheva M., Merdzhanova A., Dobreva D.A., Makedonski L. 2014 - Common carp (Cyprinus caprio) and European catfish (Silurus glanis) from the Danube River as sources of fat-soluble vitamins and fatty acids - Czech J. Food Sci. 32: 16-24.

Stillwell W., Jenski L.J., Crump F.T., Ehringer W. 1997 Effect of docosahexaenoic acid on mouse mitochondrial membrane properties - Lipids 32: 497-506.

Sushchik N.N., Gladyshev M.I., Kalachova G.S. 2007 - Seasonal dynamic of fatty acid content of a common food fish from the Yenisei river, Siberian grayling, Thymallus arcticus - Food Chem. 104: 1353-1358.

Suzuki H., Tamura M., Wada S., Crawford M.A. 1995 - Comparison of docosahexaenoic acid with eicosapentaenoic acid on the lowering effect of endogenous plasma cholesterol in adult mice - Fish. Sci. 61: 525-526.

Szatrowski T.P., Nathan C.F. 1991 - Production of large amounts of hydrogen peroxide by human tumor cells Cancer Res. 51: 794-798.

Tocher D. 2003 - Metabolism and functions of lipid and fatty acid in Teleost fish - Rev. Fish. Sci. 11: 107-184.

Toit-Kohndu J.L., Louw L., Engelbrecht A.M. 2009 Docosahexaenoic Acid Induces Apoptosis in Colorectal Carcinoma Cells by Modulating the PI3 Kinase and p38 MAPK Pathways - J. Nutr. Biochem. 20: 106-14.

Trombetta A., Maggiora M., Martinasso G., Cotogni P., Canuto R.A., Muzio G. 2007 - Arachidonic and docosahexaenoic acids reduce the growth of A549 human lung-tumor cells increasing lipid peroxidation and PPARs - Chem. Biol. Interact. 165: 239-250.
Tsujita-Kyutoku M., Yuri T., Danbara N., Senzaki H., Kiyozuka Y., Uehara N., Takada H., Hada T., Miyazawa T., Ogawa Y., Tsubura A. 2004 - Conjugated docosahexaenoic acid suppresses KPL-1 human breast cancer cell growth in vitro and in vivo: potential mechanisms of action - Breast Cancer Res. 6: R291-R299.

Ugoala C., Ndukwe G.I., Audu T.O. 2009 - Fatty acids composition and nutritional quality of some freshwater fishes - Nature Proceedings, Doi:10.1038/npre. 32391.1.

Vaughan V.C., Hassing M.R., Lewandowski P.A. 2013 Marine polyunsaturated fatty acids and cancer therapy Brit. J. Cancer. 108: 486-92.

Wang D., Lippard S.J. 2005 - Cellular processing of platinum anticancer drugs - Nat. Rev. Drug Discov. 4: 307.

Warner T.D., Mitchell J.A. 2004 - Cyclooxygenases: new forms, new inhibitors, and lessons from the clinic FASEB J. 18: 790-804.

Yang T., Fang S., Zhang H.X., Xu L.X., Zhang Z.Q., Yuan K.T., Xue C.L., Yu H.L., Zhang S., Li Y.F., Shi H.P. 2013 - n-3 PUFAs have antiproliferative and apoptotic effects on human colorectal cancer stem-like cells in vitro - J. Nutr. Biochem. 24: 744-753.

Zajdel A., Wilczok A., Chodurek E., Gruchlik A., Dzieroewicz Z. 2013 - Polyunsaturated Fatty Acids Inhibit Melanoma Cell Growth In Vitro - Acta Pol. Pharm. 70: 365-369.

Zijlstra J.G., deVries E.G.E., Muskriet F.A.J., Martini I.A., Timmer-Bosscha H., Mulder N.H. 1987 - Influence of docosahexaenoic acid in vitro on intracellular adriamycin concentration in lymphocytes and human adriamycin-sensitive and resistant small-cell lung cancer cell lines, and on cytotoxicity in the tumor cell lines - Int. J. Cancer 90: 850-856. 